\title{
Effects of summer grazing and fertiliser on the clover content of hill country swards in the Gisborne region
}

\author{
C.J. Korte ${ }^{1}$ and S.J. Quilter* \\ MAFTech, Flock House', Bulls and Gisborne ${ }^{2}$
}

ABSTRACT Preliminary results are presented from an investigation to identify reasons for the low clover content of hill country pastures in the Gisborne-East Coast region. Four experiments were established near Gisbome. Treatments included: fetiliser versus no fertiliser; summer grazing versus no summer grazing, and clover cultivars (transplanted into swards). Summer rainfall had the major influence on the clover content of swards. With a reliable high summer rainfall the clover content averaged $16 \%$ of herbage. By contrast, with less reliable and lower summer rainfall, the clover content averaged $4-5 \%$ and subterranean clover was more important, Summer spelling of pasture, which allowed rank grass growth, reduced both white and subterranean clover content of swards. Fertiliser inputs increased the clover content of swards. Performance of cultivars was affected by grazing, differences between cultivars being greatest with summer grazing. The small-leaved cultivars of white clover ('Grasslands Tahora' and 'Whatawhata') initially performed better than larger-leaved cultivars at the high summer rainfall site, but failed to sustain any advantage. 'Tallarook' subterranean clover increased the clover content of swards with summer grazing.

Keywords white clover, subterranean clover, East Coast, hill country, fertiliser, grazing management

\section{INTRODUCTION}

Hill country pastures in the Poverty Bay-East Coast Region typically have a low legume content, especially in coastal areas with less reliable summer rainfall. Possible reasons for a low legume content include: inadequate fertiliser (Suckling 195 9a) unsuitable grazing management (Suckling 1959, Sheath \& Boom 1985), or the use of inferior cultivars (Williams et al. 1982). The preliminary results reported in this paper come from a series of experiments designed to evaluate the relative importance of these factors on legume content of swards. The experiments were part of a series to evaluate white and subterranean clover cultivars in hill country swards (Macfarlane et al. 1990).

\section{METHODS}

Experiments were established on hill country sheep and beef farms at Tokomaru Bay, Ngatapa (near Gisborne),
Wairoa and Matawai in 1985. Details of trial sites and treatments are shown in Table 1. The basic experimental design was a blocked split-split-plot design, with main plots (grazing treatment) being fenced, sub-plots (fertiliser treatment) being $220 \mathrm{~m}^{2}$ and sub-sub plots being clover cultivars transplanted into swards (Macfarlane et al. 1990).

Two grazing treatments were compared: (Grazed) normal farmer grazing management through the year, and (Ungrazed) closed from grazing during summer (November-March) with normal grazing for the remainder of the year. Grazing treatments started in November 1986. Two fertiliser treatments were compared: (Normal) normal fertiliser applications (none during experiment at Matawai and Ngatapa), and (Extra) extra fertiliser $(500 \mathrm{~kg} / \mathrm{ha}$ potassic serpentine superphosphate (0:6:8:7) annually, $140 \mathrm{~g} / \mathrm{ha}$ sodium molybdate in 1986, $1 \mathrm{t} /$ ha lime in 1985). 'Grasslands Huia' feathermark was included among the white clover cultivars evaluated.

Measurements taken were: herbage mass (pasture cuts) and composition (dissections) on each fertiliser (sub) plot monthly; annual point analysis (Radcliffe \& Mountier 1964) in September along the lines (subsub-plots) where clover seedlings had been transplanted (described in Macfarlane $\boldsymbol{e t}$ al. 1990); annual counts of surviving Huia feathermark white clover plants; and soil samples for chemical analysis every 6 months. Pasture cuts and soil samples were taken at random from sub plots, but avoiding the lines where clovers had been transplanted.

For statistical analysis, monthly pasture mass and composition measurements were averaged within seasons (winter = June, July, August) and for the period December 1986 to November 1988.

For each site a monthly water balance was calculated (McAneney \& Kerr 1984) to obtain an estimate of actual to potential evapotranspiration (AET/PET), and the values were averaged for November-April.

\section{RESIJLTS}

\section{Soil tests}

Extra fertiliser applications had little effect on soil test values, although phosphate and $\mathrm{pH}$ were increased (Table 2). Based on these soil tests and other local research (O'Connor \& Gray 1984, Gray et al. 1989), expected nutrient responses (to Extra fertiliser) at each site were: Tokomaru Bay possibly molybdenum, Ngatapa phosphate, Wairoa phosphate and potassium, and Matawai possibly potassium. 


\section{Clover content of swards}

White clover and subterranean clover were the main legumes at all sites, contributing 90-100\% of clover herbage mass.

Matawai was the most favourable site for white clover (Table 3 ), the species contributing $16 \%$ of herbage mass in the Grazed Normal fettiliser treatment. This site had the highest rainfall (Table 1 ), and highest average AET/PET (0.96).

At the other 3 sites, the clover content of swards was considerably lower than at Matawai, white and subterranean clover together contributing $4-5 \%$ of herbage mass in the Grazed Normal fertiliser treatment (Table 3 ).

Summer rainfall influenced the clover content of swards, and the balance of white and subterranean clovers. Increased summer rainfall resulted in a higher AET/PET. The ratio AET/PET declines as soils dry out and further AET is limited by the high energy demand for evaporation. Values close to 1 indicate a low water stress and declining values increasing stress. Average AET/PET was correlated with the white clover content of swards in spring (Figure 1). The correlation was higher when AET/PET was averaged for the two previous years $\left(\mathrm{r}=0.798^{* *}\right)$ than when only the previous growing season was considered $\left(r=0.620^{*}\right)$.

Fertiliser application tended to increase clover herbage mass, the increase being the greater where swards were ungrazed over summer (Table 3). At Ngatapa and Wairoa, fertiliser responses were detected at the first point analysis, 2 months after the first fertiliser application.

Grazing of pasture in summer generally decreased the mass of clover (Table 3). At Matawai, despite the decrease in mass, summer grazing significantly $(\mathrm{P}<0.01)$ increased the percentage of white clover in swards $(15 \%$ and $11 \%)$. At Ngatapa: grazing did not significantly $(\mathrm{P}<0.05)$ affect white clover percentage; summer grazing significantly $(\mathrm{P}<0.05)$ increased subterranean clover percentage in winter $(2 \%$ and $4 \%)$, and decreased it in spring where extra fertiliser had

Table 1 Details of experimental sites and treatments

\begin{tabular}{|c|c|c|c|c|}
\hline Experiment & Tokomaru Bay & Ngatapa & Wairoa & Matawai \\
\hline Map reference 1 & N80 644995 & N98 157534 & N106 835035 & N88 902713 \\
\hline Altitude (m) & 200 & 150 & 20 & 620 \\
\hline Land class ${ }^{2}$ & Vle 1 & VIIe5 & IIIs 3 & VIe3 \\
\hline Soil group & $\begin{array}{l}\text { Yellow-brown } \\
\text { earth }\end{array}$ & $\begin{array}{l}\text { Skeletal yellow- } \\
\text { brown pumice }\end{array}$ & $\begin{array}{l}\text { Yellow-brown } \\
\text { pumice }\end{array}$ & $\begin{array}{l}\text { Yellow-brown } \\
\text { pumice }\end{array}$ \\
\hline $\begin{array}{l}\text { Rainfall (mm) } \\
\text { Annual } \\
\text { Jan-Mar }\end{array}$ & $\begin{array}{r}1490 \\
330\end{array}$ & $\begin{array}{c}1100 \\
230\end{array}$ & $\begin{array}{r}1490 \\
340\end{array}$ & $\begin{array}{r}1930 \\
390\end{array}$ \\
\hline $\begin{array}{l}\text { Dominant vegetation } \\
\text { Grasses }\end{array}$ & Ryegrass & $\begin{array}{l}\text { Sweet vernal } \\
\text { Ryegrass }\end{array}$ & $\begin{array}{l}\text { Sweet vernal } \\
\text { Ryegrass }\end{array}$ & $\begin{array}{l}\text { Yorkshire fog } \\
\text { Browntop }\end{array}$ \\
\hline Clovers & $\begin{array}{l}\text { Subterranean } \\
\text { White }\end{array}$ & Subterranean & Subterranean & White \\
\hline $\begin{array}{l}\text { Treatments (replicates) } \\
\text { Main plots } \\
\text { Sub-plots } \\
\text { Sub-sub-plots }\end{array}$ & $\begin{array}{l}\text { Grazing ( I ) } \\
\text { Fertiliser (4) } \\
\text { Clovers }\end{array}$ & $\begin{array}{l}\text { Grazing (4) } \\
\text { Fertiliscr (I) } \\
\text { Clovers }\end{array}$ & $\begin{array}{l}\text { Fertiliser (4) } \\
\text { Clovers }\end{array}$ & $\begin{array}{l}\text { Grazing (4) } \\
\text { Fertiliser (I) } \\
\text { Clovers }\end{array}$ \\
\hline
\end{tabular}

'Department of Lands and Surveys, NZMS 1

${ }^{2}$ Land use capability classification from National Water \& Soil Conservation Land Inventory worksheets.

Table 2 Effect of fertiliser treatments on soil test values (MAF Quicktest, O-75 mm depth).

Average of samples taken over 2 years.

\begin{tabular}{|c|c|c|c|c|}
\hline Experiment & Tokomaru Bay & Ngatapa & Wairoa & Matawai \\
\hline \multicolumn{5}{|l|}{ Acidity $(\mathrm{pH})$} \\
\hline Extra fertiliser & 5.4 & 5.7 & 5.6 & 5.7 \\
\hline Normal fertiliser & 5.3 & 5.6 & 5.6 & 5.6 \\
\hline SED & 0.03 & 0.01 & 0.03 & $0.02^{\mathrm{F}}$ \\
\hline \multicolumn{5}{|l|}{ Olsen phosphate } \\
\hline Extra fertiliser & 20 & 12 & 9 & 23 \\
\hline Normal fertiliser & 17 & 7 & 7 & 21 \\
\hline SED & $0.7^{r}$ & $0.8^{\mathrm{I}}$ & 0.7 & 1.7 \\
\hline \multicolumn{5}{|l|}{ Potassium } \\
\hline Extra fertliser & IO & I I & 4 & 6 \\
\hline Normal fertiliser & 10 & IO & 4 & 6 \\
\hline SED & 0.9 & 0.5 & 0.5 & 0.3 \\
\hline
\end{tabular}

F Fertiliser treatments significantly different $(\mathrm{P}<0.01)$ 
been applied (10\% and 5\%). At Tokomaru Bay: summer grazing significantly $(\mathrm{P}<0.05)$ increased white clover content with extra fertiliser application (8\% compared with $4 \%$ ), but not with normal fertiliser applications.

In the Grazed Normal fertiliser treatment, Tallarook subterranean clover persisted best of the cultivars evaluated, and white clover content of swards was generally little affected by introduction of cultivars (Macfarlane et al. 1990). However, these responses were modified by grazing treatments (Table 4). At Matawai, the small-leaved cultivars of white clover ('Grasslands Tahora' and 'Whatawhata early flowering') increased the clover content of swards in 1987 with summer grazing, but not where swards were ungrazed. Similar effects were not apparent in 1988. At Ngatapa, 'Tallarook' markedly increased the clover content of swards with summer grazing, but not where pasture was ungrazed in summer.

\section{White cloves transplant survival}

Survival of feathermark white clover transplants averaged $78 \%$ from planting in May to the first measurements in September 1985 (Table 5). Of the feathermark plants established in September 1985. on average 3\% still survived in September 1988. survival being best at Matawai.

\section{DISCUSSION}

Where summer rainfall was highest and most reliable (Matawai) white clover was the main legume, and the clover content of swards was acceptable ( $16 \%$ ) under normal farmer grazing and

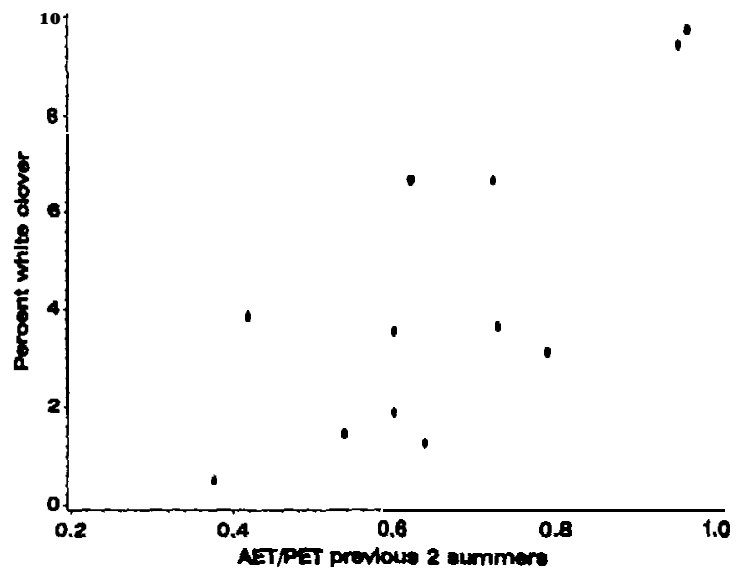

Figure 1 White clover content of swards in spring and estimated AET/PET. AET/PET was calculated for each month, and averaged for November-April of the two preceding summers.

fertiliser inputs. Where summer rainfall was lower and/or less reliable (Tokomaru Bay, Ngatapa, Wairoa) both subterranean clover and white clover contributed. and the clover content was relatively low $(4-5 \%)$. Application of substantial amounts of fertiliser. grazing treatment (Table 3), or introduction of new cultivars (Macfarlane et a/. 1990), although affecting the legume content of swards, had little effect compared with rainfall.

As expected. fertiliser inputs stimulated clovers, The increase in clover mass tended to be greater where swards were not grazed in summer (Table 3 ) because differences in clover growth were reflected

Table 3 Effect of treatments on white clover mass. subterranean clover mass. and total herbage mass (kg DM/ha). Mean of monthly measurements over 2 years.

\begin{tabular}{|c|c|c|c|c|}
\hline Experiment & Tokomaru Bay & $\mathrm{Ngatapa}$ & Wairoa' & Matawai \\
\hline \multicolumn{5}{|l|}{ White clover mass } \\
\hline Grazed. normal fertiliser & 60 & 20 & 10 & 200 \\
\hline Grazed. extra fertiliser & 120 & 30 & 80 & 230 \\
\hline Ungrazed, normal fertilise & 90 & 20 & & 290 \\
\hline Ungrazed, extra fertiliser & 90 & 60 & & 490 \\
\hline $\mathrm{SED}^{3}$ & $17^{61}$ & $14^{\mathrm{cit}}$ & 22 & 49G.I . GF \\
\hline \multicolumn{5}{|l|}{ Sublcrancall clover mass } \\
\hline G razed, nomal fertilises & 30 & 30 & 30 & \\
\hline Graced extra fertiliser & 20 & 30 & 50 & \\
\hline Ungrazed, normal fertilise & 70 & 50 & & \\
\hline Ungrazed, extra lertiliser & 90 & 60 & & \\
\hline SLDi & 18 & 12 & 20 & \\
\hline \multicolumn{5}{|l|}{ Total herbage mass } \\
\hline Grazed, nomal ferriliser & 1780 & 1040 & 1120 & 1270 \\
\hline Grazed, extra lertiliser & 1850 & 1020 & 1420 & 1340 \\
\hline Ungrazed, nommal fertiliser & 2310 & 2470 & & 2490 \\
\hline Uningrawed extra Ertiliser & 2340 & 2720 & & 2870 \\
\hline SEI & 108 & $60^{\text {(i.cit }}$ & 285 & $132 \div .6$ \\
\hline
\end{tabular}

No ungrazed treatment

- No subterrancan clover at Matawai

Standard error of difference for Grazing by Fertiliser interaction
(; Grazing treatments significantly different $(P<0.05)$

1. Fertiliser treatments significantly different $(\mathrm{P}<0.05)$

(i) Grazing by Fertiliser interaction significant $(P<0.05)$ 
in differences in herbage accumulation. With summer grazing, differences in clover growth (which undoubtedly occurred) were not always detected in pasture cuts. Responses to fertiliser tended to be most rapid at Wairoa and Ngatapa, where nutrient deficiencies (as indicated by soil test) were greatest.

Interpretation of grazing effects was difficult because throughout the measurement period differences in total herbage mass occurred, and these differences confound the interpretation of results. However, results from Matawai (both herbage dissections and point analysis) indicated that summer spelling of pasture reduced the percentage of white clover in swards compared with grazing. Responses of white clover to spelling depend on the timing and length of the summer spell, and the associated reproductive growth by grasses. Suckling (1959) obtained best white clover contents where pastures were grazed to remove grass reproductive growth, then spelled from the end of December to early March to encourage vegetation growth. Sheath \& Boom (1985) obtained best white clover contents where hard grazing (November to early January) reduced grass dominance, particularly when followed by a spell during the dry period (until March). Spelling was from November to late March in these experiments, and this resulted in rank reproductive grass growth and restricted clover growth.

Sheath \& Boom (1985) reported that spelling during January to mid March markedly reduced subterranean clover, mainly because short pastures are required by subterranean clover for successful regeneration in autumn. A similar trend was evident at Ngatapa in spring, with summer spelling
Table 5 Percentage survival of feathermark Huia white clover plants at each trial site.

\begin{tabular}{lrrrrr}
\hline Experiment & Tokomaru & Bay & Ngatapa & Wairoa & Matawai \\
\hline Seedlings planted' & 800 & 800 & $\mathbf{4 0 0 ^ { 2 }}$ & 800 \\
Percent survival & & & & \\
Septernber 1985 & 76 & 77 & 86 & 73 \\
September & 1986 & 17 & 9 & $\mathbf{3}$ & 30 \\
September & 1987 & 4 & & $\mathbf{0}$ & 10 \\
September & 1988 & 4 & $0 .:$ & 0 & 5 \\
\hline
\end{tabular}

'Seedlings transplanted in May 1985.

${ }^{2}$ Fewer plots because no grazing treatments.

removing any advantage of Tallarook (Table 4). Suckling (1959) also found that periodic summer spells from grazing decreased the subterranean clover content of hill swards.

In these experiments white clover seedlings were transplanted, and they established satisfactorily. As also found by Charlton (1984), survival of feathermark Huia transplants was relatively poor (Table 5), and the result illustrates the difficulty of improving the white clover content of hill country swards by introducing new cultivars. Compared with transplants, oversown seed would face additional difficulty establishing.

Tahora and Whatawhata white clovers initially appeared better suited to wet hill country than other cultivars (Table 4), provided grazing allowed the opportunity for expression of potential. However, the lack of difference between white clovers at Matawai in 1988 suggests that, as with feathermark Huia, the small-leaved cultivars had poor persistence, and failed to sustain an increased clover content.

Table 4 Effect of grazing treatment on clovers as measured by point analysis in spring (transformed total hits per 100 points).

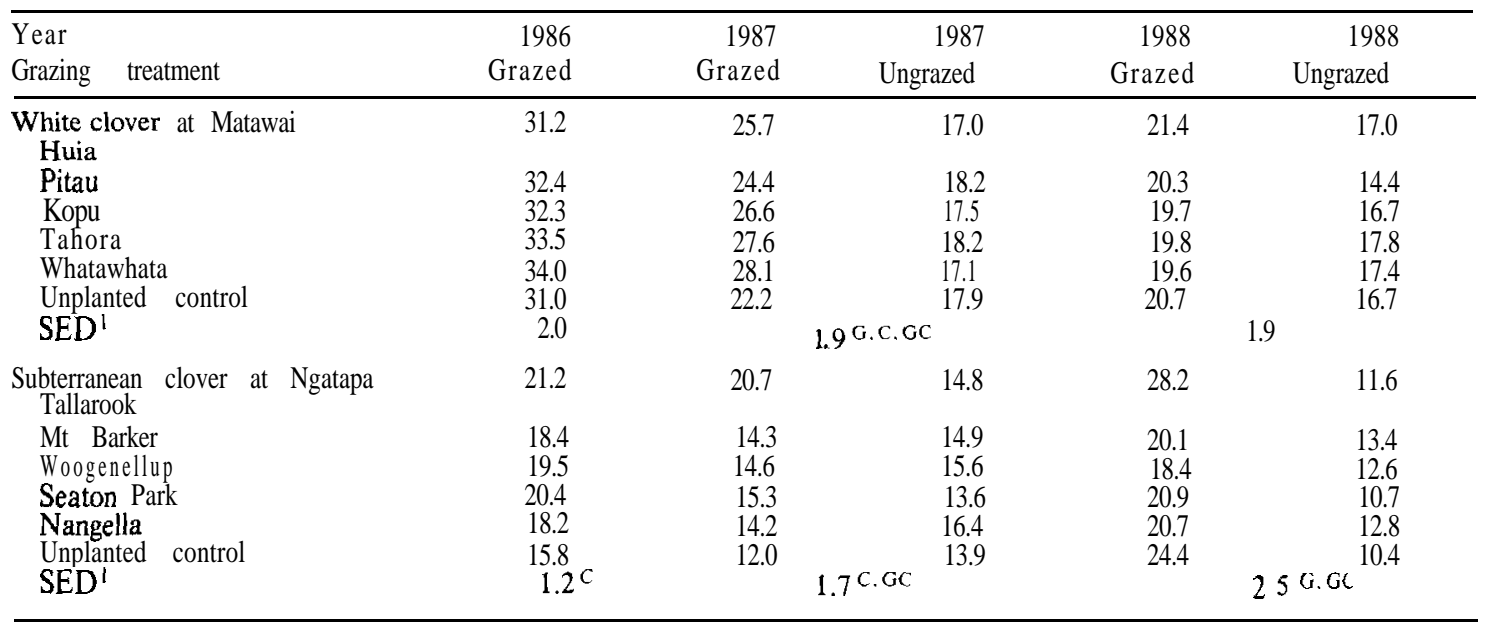

SED for grazing by clover interaction

$C$ Differences between clovers significantly different $(\mathrm{P}<0.05)$

$G$ Differences between grazing treatments significantly different $(P<0.05)$

GC Grazing by clover interaction significant $(P<0.05)$ 


\section{CONCLUSIONS}

Summer rainfall was clearly the main factor limiting the legume content of hill swards in the Gisbome East Coast region. Summer grazing management, fertiliser and better adapted cultivars all contributed to legume performance, but the effects were small compared with that of rainfall.

Summer spelling was tested to determine if rank summer pastures, as often occur in the region, influenced clover content of swards. It was concluded that allowing rank pasture to accumulate in summer reduced the white and subterranean clover content of hill country swards. However, careful timing of summer spelling can be used to increase white clover (Suckling 1959; Sheath \& Boom 1985), provided management takes account of slope and subdivision (Sheath et al. 1984).

Fertiliser stimulated clovers, and declining fertiliser use in large areas of hill country can be expected to reduce clover growth.

Further plant breeding is needed to develop clover cultivars for hill country. Currently available white clover cultivars appear to lack persistence. The best subterranean clover, 'Tallarook', contains high levels of oestrogen which could cause sheep infertility (Barnard 1972). A subterranean clover with the agronomic attributes of 'Tallarook', and with low oestrogen levels, would undoubtedly increase the potential for animal production from dry East Coast hill country.

To increase the clover content of swards, hill country farmers should (in declining order of importance): avoid allowing development of rank pastures over summer,. especially on steep land (Sheath et $a l$. 1984); maintain soil fertility by using fertiliser; and introduce better adapted cultivars of clover when they become available.

Acknowledgements W. Busby, K. Ellmers, M. Mclldowie and R. Aires for making land and animals available; G. Sheath, M. Macfarlane and other MAF colleagues at Gisbome and Whatawhata for assistance and advice; Grasslands Division of DSIR for seed: B. Dow and N. De Silva for statistical advice.

\section{REFERENCES}

Barnard, C. 1912. Register of Australian herbage plant cultivars. Division of Plant Industry, CSIRO, Canberra.

Charlton, J.F.L. 1984. Persistence of 'Grasslands Huia' white clover (Trifolium repens L) in hill country pastures. Proceedings of the NZ Grassland Association 45:13 I-139.

Gray, M.H.; Korte, C.J.; O'Connor, M.B. 1989. Interactions between potassium and sulphur on volcanic soils on Gisbome-East Coast hill country. Proceedings of the NZ Agronomy Society 18:(in press).

Macfarlane M.; Sheath, G.W.; McGowan A.; Korte C.J. 1990. An on farm evaluation of white and subterranean clovers in North Island hill country. Proceedings of the NZ Grassland Association 51:(in press).

McAneney, KJJ.; Kerr, J.P. 1984. Environmental inputs into agronomic research: guidelines. Ministry of Agriculture and Fisheries, Wellington.

O'Connor, M.B.; Gray, M.H. 1984. Fertiliser requirements of Gisbome-East Coast hill country. Proceedings of the NZ Grassland Association 45:83-9 1 .

Radcliffe. J.E.: Mountier. N.S. 1964. Problems in measuring pasture composition in the field. Part 1. Discussion of general problems and some considerations of the point method. NZ Journal of Botany 2:90-97.

Sheath, G.W.; Boom, R.C. 1985 Effects of November-April grazing pressure on hill country. pastures. 2. Pasture species composition. NZ Joumal of Experimental Agriculture 13:329-340.

Sheath. G.W.: Webby, R.W.: Pengellv. W.J. 1984. 'Management of late spring-early summer pasture surpluses in hill country. Proceedings of the NZ Grassland Association 4.5: $199-206$.

Suckling, F.E.T. 1959. Pasture management trials on unploughable hill country at Te Awa. II Results for 1951-U. NZ Journal of Agricultural Research 2: 488-543.

Suckling, F.E.T. 1959a. The effects of topdressing and oversowing hill pastures. NZ Journal of Agricultural Research 2:153-164.

Williams, W.M.; Lambert, M.G.; Caradus, J.R. 1982. Performance of a hill country white clover selection. Proceedings of the NZ Grassland Association 43:188-195. 